\title{
THE TEXTILE AND CLOTHING INDUSTRIALIZATION CYCLE
}

\author{
TEKSTILL VE HAZIR GIYIMM SEKTÖRÜ SANAYILEŞME DÖNGÜSÜ
}

\author{
Murat A. YÜLEK \\ Kaoru NATSUDA ${ }^{* *}$ \\ K. Ali AKKEMÍK ${ }^{* *}$ \\ Mete Han YAĞMUR ${ }^{* * * *}$
}

\begin{abstract}
Starting with the industrial revolution in the United Kingdom in the 18th century, the textile and clothing (TC) sector has shown some streamlined stages and characteristics that seem to reoccur even today in a similar sequence. The TC industry develops capitalizing on the adoption of its industrial technology, creates employment for relatively low skilled labor converting them into industrial workers. At this stage it also triggers the development of other manufacturing industries through positive technical, labor or managerial spillovers. As the TC manufacturing technology is further adopted by the businesses, the sector further grows, enhances productivity and becomes part of an international supply chain. Faced with international competition, the TC sector reaches a bifurcation point when it mostly diminishes or it is transformed into a higher value-added sector through fashion, branding or technical textiles. As such, the TC industry proclaims Kaldor's growth laws. The idea is supported by several timebound country experiences which are located on the TC Cycle. The suggested streamlined stages and characteristics of the TC sector provides some valuable development policy recommendations for some African countries that are striving to industrialize as well as for countries that reached to bifurcation point on the TC Cycle, such as Turkey.
\end{abstract}

Keywords: Textile and Clothing Sector, Industrial Development, Kaldor's Growth Laws

JEL Classifications: F14, L23, L67, O14, O40, O50

\section{Özet}

İngiltere’de Sanayi Devriminin başlamasından bu yana, tekstil ve hazır giyim (THG) sektörünün gelişmesinde bazı karakteristik özelliklerin kendini düzenli olarak tekrarladığı görülmektedir. THG sektöründe nispeten düşük bir teknoloji kullanıldığından, sektörün gelişmesinin ilk aşamaları görece

* Prof. Dr., Istanbul Commerce University, Orcid Id: 0000-0001-7533-5882, myulek@ticaret.edu.tr

** Prof. Dr., Ritsumeikan Asia Pacific University, Orcid Id: 0000-0001-8034-5137, natsuda@apu.ac.jp

*** Assoc. Prof. Dr., Yamaguchi University, Orcid Id: 0000-0002-5461-4759, akkemik@yagmaguchi-u.ac.jp

**** Asst. Prof. Dr., Istanbul Technical University, Corresponding Author, Orc1d Id: 0000-0002-7630-6335, myagmur@itu.edu.tr 
düşük sermaye yatırımları gerektirir. Yine de bu düşük sermaye yatırımları, genellikle tarım sektöründe çalışan ve vasıfsız işgücü olarak değerlendirilen yüksek oranda işçiyi istihdam ederek sanayi çalışanı olmalarını sağlar ve ülkenin ürettiği toplam katma değeri arttırır. Daha bu ilk aşamada THG sektörünün teknik, işgücü ve yönetim alanlarında sağladığı pozitif dışsallıklar diğer imalat sanayilerinin de gelişmesine kakı sağlar. İleriki aşamalarda, sektöre yapılan yatırımlar ve ülkenin sermaye derinliği arttıkça, ülke artık THG sektöründe küresel tedarik zincirinin bir parçası olur. Bu gelişmeyle birlikte uluslararası rekabetle karşılaşmaya başlayan sektör bir dönüm noktasına ulaşır. Çoğu zaman, ülkedeki diğer imalat sanayi sektörleri de bu süre zarfında gelişmiş olduğu için işgücü maliyeti artar ve işgücünün hâlâ ucuz olduğu az gelişmiş ülkelerle rekabet edemeyen THG sektörünün ekonomideki ağırlığ1 giderek azalır. THG sektörünün ekonomideki yerini korumayı başarması sektörün moda, markalaşma ve/veya teknik tekstil üretimine yatırım yaparak daha yüksek katma değerli üretime geçmesine bağlıdır. Bu makalede THG sektörünün bu karakteristik özellikleri farklı ülke örnekleri incelenerek ortaya koyulmakta ve THG sektörünün gelişmesinin Kaldor'un büyüme yasalarıyla uyumlu olduğu gösterilmektedir. Elde edilen sonuçlar, henüz sanayi öncesi dönemdeki bazı Afrika ülkelerinin THG sektörünü sanayileşmeye giriş olarak kullanabilecekleri ve Türkiye gibi sektörün dönüm noktasına ulaştığı ülkelerde sektörün varlığını sürdürebilmesi için markalaşmaya ve/veya teknik tekstile yatırım yapmaları gerektiği gibi önemli sanayi politikası tavsiyeleri sunmaktadır.

Anahtar Kelimeler: Tekstil ve Hazır Giyim Sektörü, Sanayileşme, Kaldor Büyüme Yasaları

JEL Sınıflandırması: F14, L23, L67, O14, O40, O50

\section{Introduction}

Textile and clothing (TC) industries have played a pioneering role in the overall industrialization of the UK during the industrial revolution in the 18th century. They have played a similar role in the industrialization of a number of other countries including Japan and Turkey; and this process seems to recur even in the 21th century in countries such as Bangladesh and Cambodia where the rise of the local TC industry helps with employment opportunities and growth. Meanwhile, early developers have subsequently lost their TC industries mostly due to cost differentials with newly developing countries. Some of these countries have mostly abandoned TC industries while others have transformed them into higher value added sectors through branding (fashion industry) or developing technical textiles products.

As such, the TC industry proclaims Kaldor's growth laws that suggest growth rate of an economy is positively related to its manufacturing sector. It is based on the reasoning that, in early stages of development, manufacturing sector has increasing returns the scale. As the manufacturing sector expands and draws labour from other sectors, where diminishing returns to scale persist, output and productivity in the overall economy increases. Though, the degree of overall productivity growth induced by manufacturing growth is likely to diminish as the scope for transferring labour from diminishing returns activities tails off (Kaldor, 1966, 1967).

Between the birth of the industrial TC and its demise or transformation, the industry goes through four distinct phases. In the first phase of the cycle, TC production, at the industrial level, emerges and grows slowly. In the second stage growth accelerates when TC starts to become a large industrial sector in terms of employment, gross value added and exports. During these two 
phases, the TC production positively triggers or assists development of other industrial sectors through technical, technological and managerial spillovers. In the subsequent phase, the TC sector "matures" displaying low or zero growth rates, and falling shares in total value added or exports of the country. At some point, other manufacturing sectors may overtake TC in terms of, again, employment, gross value added or exports. In the last phase, TC production either by and large disappears or gets transformed and remains at a lower intensity compared to before; we have identified three key transformations: fashion, branding and technical textiles.

The TC Cycle and its continuing recurrence can be considered a stylized fact (or rather a "stylized regularity") in the Kaldorian lines. ${ }^{1}$ It is based on the observation of a number of country experiences so far. A number of factors relating to demand, cost and pricing of TC products seem to play a role in the recurrence of the TC Cycle. Firstly, the demand for TC products remains. Further, the interplay between four different economic and technological trends seem to cause the recurrence of the TC Cycle in different countries since the 18th century: (i) manufacturing cost differentials between high and low income countries, (ii) the technology of basic textile manufacturing as well as technology of newer TC products; (iii) branding; (iv) fashion activities.

In the next section we introduce the idea of the TC Cycle. In the third section we review the country case studies. The last section concludes the paper.

\section{The Textile and Clothing Sector and Industrial Development Cycle}

Textile and clothing (TC) is a labor intensive industry that requires relatively low-skilled labor compared to other industrial sectors such as automobile manufacturing, foundries and electronics. For a developing country, it provides a critical entry point for the unskilled workforce into the labor market; it typically converts low-skilled labor into industrial workers. Due to this characteristic, TC played a pioneering role in the industrial revolution in the UK in the 18th century. ${ }^{2}$ Moreover, in many countries, such as the US, Japan and Korea in the past and Bangladesh or Cambodia today, TC was a trigger of the general industrialization process.

There are some differentiating factors between the textile and the clothing sectors. The clothing sector is more labor and less knowledge intensive. It requires lower level of capital investments and maintenance costs than the textile sector. Nevertheless, despite the differing characteristics, the two sectors have been highly interdependent historically; and their interdependence has been retained under the modern production techniques. Moreover, as the textile sector supplies inputs to the clothing sector, they often develop in tandem.

1 The term "stylized fact" has been minted by Kaldor (1961) referring to broad generalizations and simplified presentations of observational and statistical evidence.

2 Cameron and Neal (2003). A Concise Economic History of the World: From Paleolithic Times to the Present, New York, Oxford University Press, p. 179. 
A typical TC cycle can be contemplated and juxtaposed with an overall industrialization cycle (Figure 1). In the first stage of the cycle, TC develops slowly and catalyzes, with a lag, a sectorally more widespread Kaldorian industrialization process. That is, the TC sector provides a base for capital and knowledge accumulation and triggers development of other manufacturing and non-manufacturing sectors.

In the second stage, TC industrialization and growth accelerate, again, enhancing the growth of the general industrial sector through Kaldorian lines, though still with a lag. Internationalization is an important component of this stage. Unlike before, in today's world, local TC businesses internationalize by becoming part of well-established international supply chains. Production and management (e.g. delivery time) quality increases overtime. That can be considered a part of a learning process with positive spillovers to other manufacturing and non-manufacturing industries.

In the third stage, the growth rate of the TC, and, with a lag, that of overall industry flattens towards zero. That takes the TC sector until a "bifurcation" point. This stage can last short or get extended. In Stages I, II and III, the TC production is likely to be entirely a "commodity" business where the product is not differentiated and the producer is a price taker. It may prove very difficult for a country and its TC businesses to sustain itself, for extended periods of time in Stage III due to increasing cost competition from emerging low-cost countries that are in the stage I or stage II of their TC cycle.

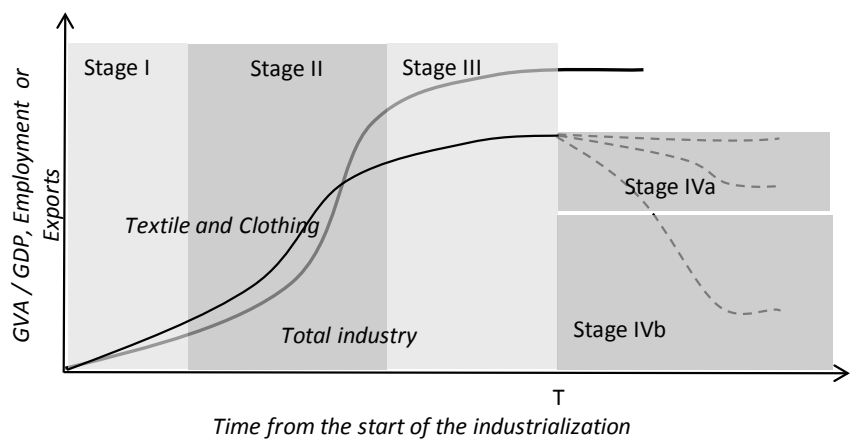

Figure I. The Textile and Clothing Cycle Along with the Industrialization Cycle

Consequently, the bifurcation point may lead to a sharp downward trend in TC production in terms of share in total industry or even in terms of absolute total value added (Stage IVa) accompanying further manufacturing or non-manufacturing diversification. This is a case where TC is largely abandoned, such as in Japan following a diversification of the industrial structure into other manufacturing and non-manufacturing sectors.

Alternatively, the TC sector in the country may continue its vitality by a transformation that increases its non-manufacturing value added (Stage IVa). This transformation can be towards branding or fashion (such as in Italy, France and the UK) or towards new and technological products (such as technical textile in Germany or USA where technical textiles constitute 
around 50 percent of total textile production) $)^{3}$. Both of these latter avenues are types of product differentiation that increases the pricing power of the producer.

The TC cycle recurs over time, reincarnating in different countries since the rise of the industrial TC in the UK in the 18th century. The recent TC industrializers face different barriers and environment such as "full package production" rather than "assembly production" demanded by large retailers in the developed economies which represent the main market for TC products. A key feature that causes the recurrence of TC Cycle in different countries is that the basic labor demand for TC production process (in terms of traditional textiles and garments, home textiles and more recently technical textiles) remains with varying degrees. Given the sustained demand for TC products, the interplay between four different economic and technological trends seem to cause the recurrence of the TC Cycle in constantly changing countries since the 18th century: (i) manufacturing cost differentials between high and low income countries, (ii) the technology of basic textile manufacturing as well as technology of newer TC products; (iii) branding; (iv) fashion activities.

\section{Country Case Studies}

In this section, we review the TC cycle in selected countries. The case studies demonstrate that the TC cycle has been recurring since the 18th century. We try to locate various episodes in each country on the TC cycle (Figure 2). The UK and Japan, two key TC exporters at the global level during the 19th century, have abandoned the TC manufacturing broadly after 1970s. The UK now has a fashion industry that is largely domestic and currently continues to generate most of the gross value added through wholesale and retail marketing of the TC products. The USA, another global pioneer in TC sector, has shifted to technical textiles and still remains one of the relatively larger TC exporters. Turkey, which has developed its TC industry during the 20th century and is also among the largest TC exporters currently, has now reached the maturing stage. Bangladesh and Cambodia, fast growers in TC today, are experiencing the rapid growth stage.

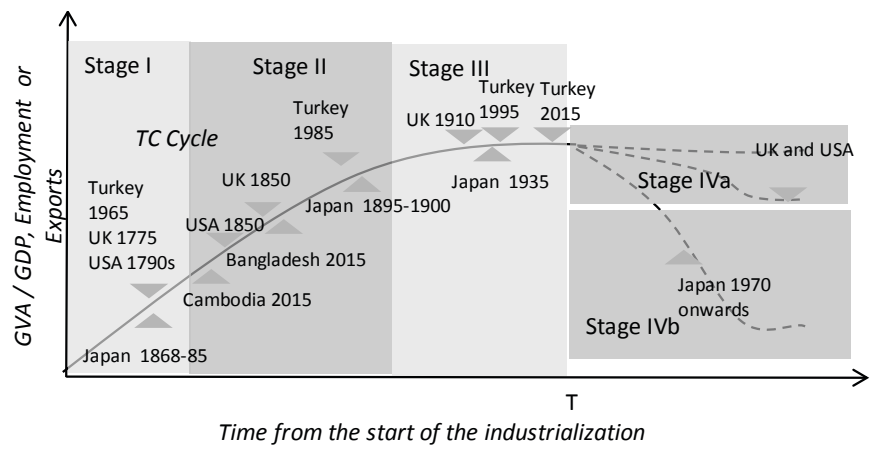

Figure 2. Location of Country Experiences on the TC Cycle

3 Messe Frankfurt (2011). Technical textiles - a market with enormous potential, http://www.fibre2fashion.com/ news/company-news/messefrankfurt/newsdetails.aspx?news_id=94612 (Accessed On: 17.05.2015) 


\section{I The United Kingdom}

The UK was the global pioneer in the development of the industrial TC sector during the first industrial revolution when TC registered a drastic growth and played a key role in the development of the industrial sector. Cameron and Neal (2003, p.179) note that "the technical changes involving cotton textiles, the iron industry, and the introduction of steam power constitute the nucleus of early industrialization in Britain" ${ }^{4}$ The UK accounted for over 80 percent of total world textile exports in early 1880s (Table 1). In the second half of the 19th century, English textile mills accounted for 40 percent of Britain's exports and one-fifth of Britain's population were directly or indirectly involved with cotton textiles. ${ }^{5}$ Following a bumpy decline path, the TC manufacturing in the UK today has diminished significantly whereas a fashion industry (mostly relating to the domestic market) has developed. Consequently, the UK can best be identified as a Stage IVb country today.

Table I. Shares of Countries in World Textiles Exports.

\begin{tabular}{|l|l|l|l|l|l|}
\hline & UK & France & USA & India & Japan \\
\hline $\mathbf{1 8 8 2 - 4}$ & 82.0 & 14.3 & 2.8 & 0.9 & - \\
\hline $\mathbf{1 9 1 0 - 3}$ & 70.0 & 20.0 & 4.2 & 1.0 & 2.1 \\
\hline $\mathbf{1 9 2 6 - 8}$ & 46.1 & 27.1 & 6.3 & 2.0 & 16.3 \\
\hline $\mathbf{1 9 3 6 - 8}$ & 26.9 & 21.5 & 3.9 & 3.1 & 38.9 \\
\hline $\mathbf{1 9 4 9}$ & 19.7 & 31.4 & 19.3 & 10.1 & 16.2 \\
\hline $\mathbf{1 9 5 5}$ & 11.8 & 28.8 & 11.5 & 16.3 & 24.2 \\
\hline
\end{tabular}

Source: Rose, M. (1991). International Competition and Strategic Response in the Textile Industries since 1870, Business History, 32(4), p.3.

A number of factors were critical in the UK's TC industrialization process. Firstly, the UK established an international supply chain importing large amounts of low cost cotton primarily first from India and then from its North American colonies through vehicles such as East India Company. Secondly, TC manufacturing developed in Northern England which had access to power (of the fast flowing rivers and then coal and steam engines), railways and ports. Thirdly, demographics of the Northern UK provided cheap labor (especially women and children) to the TC industry labor with experience in the production of woolen goods.

Fourthly, a number of technological advances such as the invention of the flying shuttle (1733), the spinning jenny (1765), Richard Arkwright's cotton yarn manufacturing factory and the water frame (1769), Watt's steam engine (1776) and iron loom (1830) increased labor productivity and thus profits in textiles. ${ }^{6}$ By the early 19 th century, all aspects of cotton fabric production could be

4 See also Clark G. (1987). Why Isn't the Whole World Developed? Lessons from the Cotton Mills, The Journal of Economic History, 47(1), p. 141.

5 Dattel G. (2009). Cotton and Race in the Making of America: the Human Costs of Economic Power. Plymouth, UK: Ivan R. Dee, p.61.

6 Harley, C. K. (1998). Cotton Textile Prices and the Industrial Revolution. Economic History Review, 51(1). 
handled under one roof. Finally, policies have also played a role. The trade restrictions ("Calico Laws") in late 18th century have protected British industry from more efficient Indian cotton industry. The repeal of the law in 1774, coinciding with the development of the cotton based TC technology and industry in the UK allowed production of better and cheaper textiles from free importation of raw cotton from India. This converted the UK into the "workshop of the world". This significantly reduced the position of India which in the 18th century was the major producer of textiles in the world (Mukund, 1992). ${ }^{7}$

Britain's cotton industry production peaked prior to World War I accounting for more than two thirds of the world exports. However, World War I had a profoundly negative effect on the industry. As the demand for cotton products plunged, mills in Manchester had to lay off workers and close down.

In the aftermath of World War I, under increasing international competition especially from Japan, the decline continued except for a short-lived rise in early 1950s. At the end of 1950s, the UK became a net importer of textiles for the first time in two centuries and by 1980s, the textile industry has almost entirely disappeared leaving behind many closed down factory buildings in Manchester.

Currently, in the UK the manufacturing of TC products is largely abandoned while a fashion industry has developed. Consequently, the country currently generates a large amount of gross value added (GVA) from fashion industry mostly derived from retail trading and very limited amount of manufacturing and exports. As presented in Table 2, (British Fashion Council, 2010, p.31) calculates the total gross value added of TC manufacturing at $£ 1,380$ million ( 0.09 percent of the UK's 2010 GDP) whereas with the inclusion of retail and wholesale trade the total TC value added rises to $£ 12,522$ million ( 0.84 percent of the UK's $2010 \mathrm{GDP}$ ). In other words, manufacturing of TC is estimated at 11.0 percent of total value added generated by the TC activities. This can be considered an evidence of a loss in manufacturing businesses in TC (and an accompanying rise in unbranded TC imports) while a rise in TC branding and fashion activities.

The fashion industry in such a form has proven to be a successful business practice for the UK economy as in 2015 GVA of the overall TC industry in the UK has increased to $£ 28,1$ billion, which is equivalent to 1.5 percent of the UK total GDP (British Fashion Council, 2015, p.6).

Table 2.UK TC Gross Value Added (£, millions) (20I0).

\begin{tabular}{|l|r|r|r|}
\hline & Manufacturing & Retail and Wholesale & Total Value Added \\
\hline Men's, Women's Children's Wear & 1,380 & 11,143 & 12,523 \\
\hline Other Fashion Goods & 1,106 & 6,832 & 7,938 \\
\hline Total & 2,486 & 17,975 & 20,461 \\
\hline
\end{tabular}

Source: British Fashion Council (2010). Value of the UK Fashion Industry, London.

7 According to Chaudhuri (1974, p. 127) before these technological advances in Britain, the Indian subcontinent was the world's greatest producer of cotton textiles. 


\subsection{Japan}

The industrialization process in Japan started with the Meiji restoration in 1868. The textile sector started to dominate the Japanese economy in the early 20th century overtaking agriculture and mining which prevailed prior to the Meiji restoration. First the Japanese government, and then private entrepreneurs imported spinning machines from Britain to produce cotton goods for the domestic market with the first set of modern spinning machinery sent to Japan in 1866 and the development of textile industry beginning around 1880s. ${ }^{8}$ Japan closely followed the English model at the onset of the textile industry. As in the other industrializing countries, growth in textile production was crucial to Japan's industrialization both in terms of output and export expansion and in terms of adoption of technology and industrial organization (Francks, 2011).

As presented in Table 3, the share of TC industry in Japan expanded rapidly after 1875; peaking in 1895. The decline from that point on does not indicate a contraction in the TC industry but rather expansion of Japanese non-textile manufacturing. Ohkawa (1979) notes that textile output grew in real terms at an annual average rate of 6.6 percent over the 1874-1940 periods including at over 10 percent per annum up to 1900. By 1925, exports constituted 45 percent of total TC production. More strikingly, in 1930 Japan surpassed the UK, the world leader in cotton textile exports (Table 1). In 1935, TC was Japan's leading export sector, constituting 60 percent of total exports. In the post-war period TC sector was still the largest export industry with a total of 1.2 million domestic employees (Farrell, 2008, p. 177). The TC sector thereby played a key role also in post-war reconstruction period.

Table 3. Textile Production and Exports in Japan.

\begin{tabular}{|l|l|l|}
\hline Year & Share of textiles in manufacturing output (\%) & Share of exports in total textile output (\%) \\
\hline $\mathbf{1 8 7 5}$ & 22.3 & 14.9 \\
\hline $\mathbf{1 8 8 0}$ & 27.9 & 10.6 \\
\hline $\mathbf{1 8 8 5}$ & 28.4 & 18.3 \\
\hline $\mathbf{1 8 9 0}$ & 36.1 & 13.1 \\
\hline $\mathbf{1 8 9 5}$ & 47.3 & 19.7 \\
\hline $\mathbf{1 9 0 0}$ & 35.8 & 24.1 \\
\hline $\mathbf{1 9 0 5}$ & 31.9 & 37.3 \\
\hline $\mathbf{1 9 1 0}$ & 33.6 & 40.0 \\
\hline $\mathbf{1 9 1 5}$ & 33.1 & 40.7 \\
\hline $\mathbf{1 9 2 0}$ & 34.3 & 38.2 \\
\hline $\mathbf{1 9 2 5}$ & 39.4 & 45.2 \\
\hline $\mathbf{1 9 3 0}$ & 30.6 & 37.2 \\
\hline $\mathbf{1 9 3 5}$ & 29.1 & 37.2 \\
\hline
\end{tabular}

Source: Francks, P. (2011). Kimono Fashion: the Consumer and the Growth of the Textile Industry in Pre-war Japan. In: Francks P., Hunter J., Editors. The Historical Consumer: Consumption and Everyday Life in Japan, 1850-2000. New York: Palgrave Macmillan.

8 Saxonhouse G. (1974). A Tale of Japanese Technological Diffusion in the Meiji period. The Journal of Economic History, 34: 149-165.

Smith, T.C. and Vucinich W.S. (1955). Political Change and Industrial Development in Japan: Government Enterprise 1868-1880. Stanford: Stanford University Press. 
Nevertheless, first because of high import tariffs imposed by countries, like China; and then, under cost pressures due to salient shift of Japanese economy from labor intensive to capital, technology and human capital intensive production, Japanese TC producers started to relocate production to other Asian countries accelerating in 1960s and 1970s. In parallel, development of TC sectors in Asian countries led Japan to lose share in export markets (McNamara, 1995). Due to the relocation or abolishing the TC production, the textiles industry in Japan lost 400,000 workers from 1960s to the mid-1980s and another 100,000 from 1990 to 2005 ending up at 40,000 which indicate that virtually all the production in Japan either abolished or carried offshore (Farrell, 2008).

Decline in textile production was apparent also in the export data. (Taniguchi, 1991) marks 1985 as the year that TC lost its role as an export industry in Japan. The textile industry generated trade deficit for the first time in 1987. Consequently, the share of textiles in the total annual value of Japanese exports exhibited a striking decline from 30 percent in 1960 to 2.5 percent in 1990 (McNamara, 1995). The share of TC industry in Japanese manufacturing kept on falling also after the 1990s and stabilized around 1.6 percent between the years 2014-2016 (Figure 3).

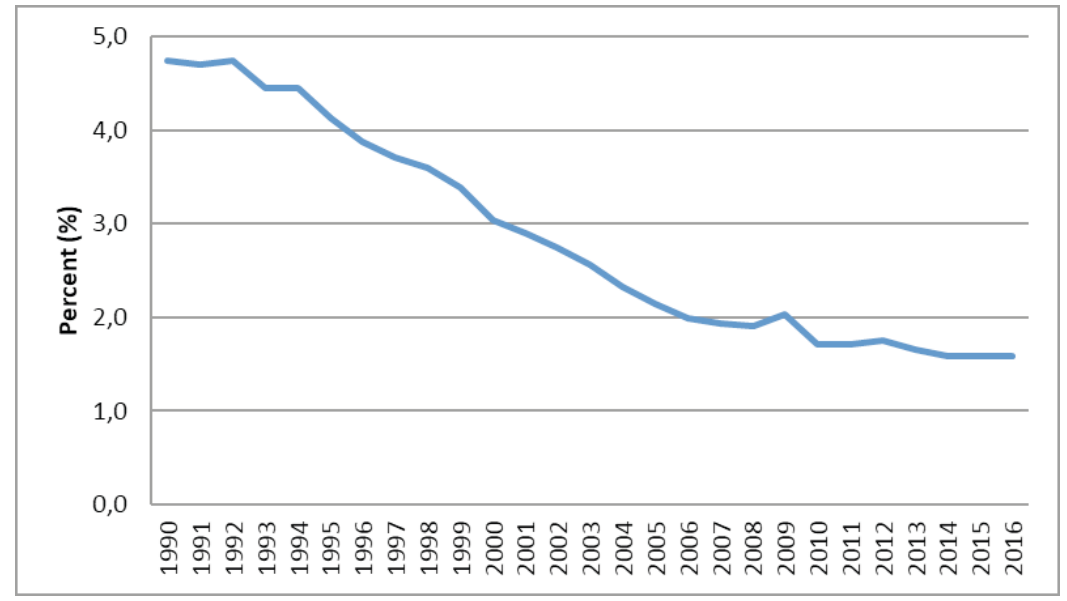

Figure 3. Japan: Share of TC Value Added in Manufacturing.

Source: WB, World Development Indicators, 2019.

In sum, TC played a key role in the industrialization of Japan. Japan adopted the textile industry and imitated Britain from 1868 to 1885; this period corresponds to Stage I in the TC Cycle. Total manufacturing surpasses the textile industry between 1895 and 1900, this period indicates the intersection of "textile and clothing" and "total industry" curves at Stage II (Figure 1). 1935 is the year that the Japanese textile industry peaked; it corresponds to stage III. TC sector started to decline sharply after 1960s marking the end of stage III. Following its decline, today, the TC industry constitutes a tiny share in the Japanese economy. Hence Japan's TC sector today is at Stage IVb. 


\subsection{USA}

The USA is another historical pioneer of industrial TC. From the 19th century, TC industry experienced a rise until mid-20th century and then a rapid fall in terms of production and employment. More recently, there is stabilization in the production and employment in both sectors.

A number of factors played key roles in the initial rise of TC sector. Firstly, capital accumulation based on agricultural production financed capital investments necessary to build the mills. Secondly, availability of cheap labor enabled the production. Lastly, technology transfer from the $\mathrm{UK}$ at the beginning of the 19th century was important.

On the other hand, competition from low cost manufacturers caused the fall of American TC. Technology played a complicated role. In the 1970s, capital investment in newly developing labor-saving textile technologies led to declining employment together with increasing laborproductivity, competitiveness and total production. In clothing, which is more labor intensive than textiles, labor-saving technological development was much slower and more limited. Thus, the American clothing businesses were hit more severely by the international competition from low-wage countries than were textiles businesses. However, more recently, further fall of textiles and clothing production and employment has come to a halt. Since 2010, both employment and production levels have stabilized. The key reason for this is probably again the labor-saving technologies that protect US competitiveness while that for clothing is the proximity to the large American market that cause low transportation costs and quicker turnaround times (Clifford, 2013).

\subsection{Emergence of the TC Industry in the USA}

In the USA, cotton textile manufacturing started to emerge towards the end of the 18th century, mostly in New England. Initial development of the textile manufacturing relied on the financial capital of wealthy farmers as well as low-wage labor (including female and child). ${ }^{9}$

There was a policy component as well. In 1790, Alexander Hamilton submitted his "Report on Manufactures" to the Congress. Hamilton advocated the manufacturing industry when the USA primarily had an agricultural economy. In 1791, he and others have established the "Society for the Establishment of Useful Manufactures", a state-chartered private corporation which founded the town of Paterson, New Jersey much as an "industrial zone" today. Paterson and surroundings included powerful rivers and falls which were to provide power for textile mills and other industries. In 1793, the "National Manufactory", the first water-powered textile mill (a cotton spinning mill) was established in Paterson under the leadership of Hamilton. ${ }^{10}$

9 Meyer, D. (2003). The Roots of American Industrialization. Balltimore: The Johns Hopkins University Press.

10 North Jerseys Internet Magazine. Silk City - Paterson, New Jersey. Industrial Revolution in North Jersey, http:// www.rt23.com/history/Paterson_NJ-silk_city.shtml 
Governments of both the UK and the USA were aware of the importance of textile sector and its technology. UK was keen to prevent emigration abroad of textile artisans and workers had instituted laws against emigration of textile workers. In 1816, the U.S. Congress imposed a 25 percent tariff on imported wool, cotton and manufactured iron; the rate was raised in 1824 and then in 1828 with a view to protect American manufacturing industry (Preyer, 1959 and Dangerfield, 1965).

As in the case of the UK, technology has played a role in the development of the textile sector in the USA. Known as the father of the American industrial revolution, Samuel Slater who mastered the new spinning technologies in the UK including at Arkwright and Strutt's mills, migrated to New England (Conrad, 1995). In 1792, financed by a businessman, Slater led the launching of the first successful automated yarn spinning mill in the USA (Hawke, 1988 and Garraty, 1997). Other technological developments also helped the development of textile industry in the USA. For example, Whitney and Holmes have revolutionized cotton ginning by their saw tooth gins.

Other than capital, cheap labor and power, textiles required technical skills. Production processes of the new cotton textile manufacturing diverged from those of the non-industrial manufacturing of goods such as shoes. Highly skilled mechanics were required to build the machines and to maintain them. Initially, Slater trained a lot of New England textile mechanics thus generating necessary human capital for the sustainability of industrial textiles. After 1815, power-loom weaving started to develop, especially in Massachusetts. Boston Manufacturing Company at Waltham developed large-scale and integrated cotton textile manufacturing that led to increasing efficiency. After 1830s, textile factories converted to steam power which provided a more stable and inexpensive source of power for machinery (Meyer, 2003).

\subsubsection{Recent Trends}

In the 20th century, the US textile and clothing industry has been an important source of manufacturing employment until recently. The fates of textiles and clothing, while interlinked, have been distinct. The employment and production loss in clothing following the respective peaks has been higher and more rapid with negative repercussion on textiles.

US textiles employment peaked in 1948 with 1.3 million jobs; fell rapidly until mid-1950s; and stayed roughly flat between mid-1950s and end-1960s. ${ }^{11}$ Starting with 1970s, there has been a secular downward trend. Through several business cycles, textile employment declined to 1 million in 1969, 670 thousand in 1991 and 119 thousand at end-2014.

This was due to three key factors. Firstly, during late 1960s and 1970s, the US textiles businesses made heavy capital investments (at the order of 5 to 7 percent of total turnover) through acquiring new labor-saving machineries. There has been a second wave of similar capital expenditures

11 Murray, L. (1995). Unraveling Employment Trends in Textiles and Apparel, Monthly Labor Review, August 1995: 62-71. 
between 1987 and 1990. Secondly, there have been a number of important consolidations in the sector that increased the scale of operations. The capital investments and consolidations, while leading to a reduction in labor demand caused significant productivity gains and improved international competitiveness of the American textile industry.

Despite decreasing employment, the US textile manufacturers were able to protect their share in the domestic market and even recorded a trade surplus through early 1980s as they had strengthened their competitiveness compared to businesses in the low-labor cost developing economies through the productivity gains caused by the new machinery investments. However, the US TC businesses faced increasing imports of clothing under heavy pressure from low cost overseas competitors. Increasing productivity nevertheless helped the textile production to increase until mid-1990s while employment fell.

US clothing employment, which traditionally was higher than textile employment, peaked in 1973 at 1.4 million, while production peaked in 1987 (Murray, 1995). The industry increased its capital expenditure during 1970s compared to previous two decades. Moreover, as the laborsaving technological advances were not as radical as in the textiles, the clothing businesses in the USA were less protected from low-cost competitors in the developing economies. Nevertheless, the productivity of clothing manufacturing increased at an average rate of 2.4 percent between 1979 and 1991. In 1990, 30 percent more labor was required for every dollar of output in the clothing industry than in the textile industry; thus, the scale effects are more important in clothing and the industry was under a heavier competitive pressure from the low cost countries.

Consequently, clothing imports increased rapidly, from 5.2 percent (USD 1.3 billion) of total domestic market in 1970 to 26.1 percent (USD 22 billion) in 1988. Unlike textiles, the US clothing sector has traditionally recorded trade deficits. Exports remained at less than 5 percent of production and by 1995, trade deficit in the clothing sector reached USD 35 billion (Murray, 1995). By 1996, textile and clothing exports amounted to USD 12.9 billion with the major markets consisting of North and South American countries as well as Japan. The imports, on the other hand reached USD 48.2 billion, the main exporters being East and South Asian (China, Taiwan, Hong Kong, Korea, Philippines and India) as well as North and South American countries (Mexico, Dominica Republic and Canada). ${ }^{12}$

Contrary to earlier assessments, NAFTA free trade agreement between USA and Mexico did not lead to increasing US textile production; imports surged and employment fell rapidly until early 2010. Between 1994 and 2001, textile imports have increased by 88.5 percent in square meters and 50 percent in value to USD 13.8 billion. Textile exports, on the other hand, increased by a similar 58 percent to USD 10.1 billion. This led to a contraction of the domestic production from USD 58.6 billion to USD 53.1 billion in current dollars. On the other hand, evolution of the clothing sector following NAFTA has been as expected; a large portion of the remaining US

12 Mittelhauser, M. (1997). Employment Trends in Textiles and Apparel, 1973-2005. Monthly Labor Review, August 1997: 24-35. 
apparel businesses relocated to Mexico. Clothing employment declined to 371 thousand from 837 thousand at end-1993; it further declined to 137 thousand at the end of $2008 .{ }^{13}$

Recently, both textile and clothing employment have stabilized around 24 and 15 percent of 1990 levels, respectively. The key reason for the halting of the fall in textiles is labor-saving technologies that protect US competitiveness while that for clothing is the proximity to the large American market that cause low transportation costs and quicker turnaround times (Clifford, 2013). Meanwhile, US textile exports, at USD 14 billion (4.6 percent of world exports), and US clothing exports, at USD 6 billion (1.3 percent), in 2013 reveal that the USA has international competitiveness in some segments and is still one of the largest textile and clothing exporters in the world. However, trade figures also show that USA runs significant deficits in both textiles and especially clothing. Most of the trade deficit in clothing emanates from China and Asian countries suggesting that low labor costs play a role challenging the price competitiveness of US businesses.

The development of technical textiles is another factor that explains the sustainability or remaining textile industry in the USA. Already in 1994 the US textiles industry was producing 63 percent of its output for nonapparel uses (Barrow, 2000); and US fibre consumption for technical textiles increased steadily during the 1990s and surpassed 2 million tonnes in the year 2000 (CIRFS, 2011). Furthermore, even though there is general decline in the textile and apparel employment between 1997 and 2007, workforce in the technical textile sector had slightly increased (Chi, 2010).

Nevertheless, according to CIRFS (2011) fibre consumption for technical textiles is around 1.6 million tonnes in 2010; and by 2017, the consumption is estimated to be slightly over 1.4 million tonnes. This recent negative trend could partially be explained by the fall in overall production in some sectors that use technical textiles as input. A good example is the automotive industry which is one of the largest users of industrial textiles in value in North America.

\subsection{Turkey}

Turkey is one of the oldest permanent settlements in the world and hence, one of the first places that textile production started. During the 16th and 17th century the Ottoman Empire (predecessor of modern Turkey), cotton, wool and silk were vastly produced in the region through small workshops. The first modern industrial factory in the Ottoman Empire in 1835 was a textile factory established by the state in Istanbul.

As the Republic of Turkey was established in 1923, industrialization efforts were revived and TC was one of the priority sectors. Starting from the 1950s TC factories expanded. Besides meeting the local demand, export capacity has gradually been built up with net exports increasing substantially. The share of TC in total exports (which mostly consisted of agricultural products)

13 Suh, H.O.M.W. (2003). What is Happening to the US Textile Industry? Reflections on NAFTA and US Corporate Strategies, Journal of Fashion Marketing and Management: An International Journal, 7(2): 119-37.

Gereffi, G. (2000). The Transformation of the North American Apparel Industry: is NAFTA a Curse or Blessing? Integration and Trade, 4(11): 47-95. 
increased from 0.3 percent in 1960 to 5 percent in 1970 and to 17.8 percent in 1979 . From early 1980s, Turkey started to liberalize its economy and opened up to international markets. The TC sector assumed a key role in Turkey's economic expansion in this period. The share of TC in total exports peaked at 39.2 percent in 1995; and from 1999 onwards, even though the TC exports in absolute value regularly increased, the share of TC in total exports started to decline (Figure 6).

Even after 2005, when all the quotas in the TC sector were abolished by the WTO (World Trade Organization) and the sector was challenged by competition particularly from China, Turkish TC industry kept increasing its production capacity and exports. In the year 2013 around 53,000 TC companies were carrying out operations in Turkey and according to (WTO, 2014, p. 58) and according to (WTO, 2018) the country is the World's 4th largest exporter with 26.5 billion USD worth of total exports.

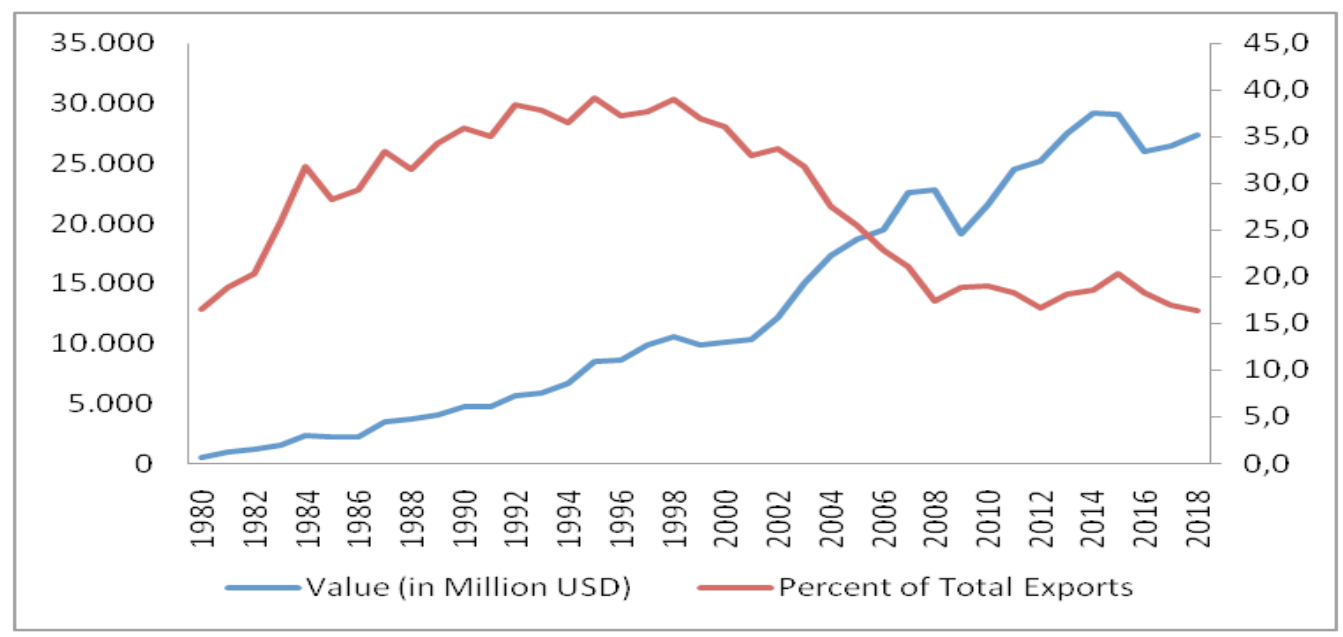

Figure 6. Turkish TC Exports.

Source: TUIK (2019). Foreign Trade Statistics.

The TC sector is also the largest net foreign exchange provider to the Turkish economy, which chronically records foreign trade deficit. From 2004 to 2013, cumulative net foreign trade surplus of the TC sector is 124 billion USD; this is larger than the sum of net foreign trade of other sectors that generate foreign trade surplus (PGlobal, 2014). Confirming this result, Table 4 presents that over the ten years between 2008 and 2017, TC sector is by far the largest sector that generates foreign trade surplus to the Turkish economy.

The TC sector in Turkey is also a significant source of employment with 1.4 million employees (5.5 percent of total employed). Total (with indirect and induced) TC employment reaches about 2.4 million constituting 9.3 percent of total employment. The TC sector absorbed a significant 
part of the unemployed labor enabling them to set up a life in urban areas, facilitating the fast urbanization process in Turkey during the past few decades.

Table 4. Cumulative Net Foreign Trade of Selected Sectors (billion USD).

\begin{tabular}{|ll|}
\hline & $2008-2017$ \\
\hline Textile and Clothing & 170 \\
\hline Manufacture of Food Products and Bevarages & 44 \\
\hline Automotive & 19.4 \\
\hline
\end{tabular}

Source: TUIK (2019) Foreign Trade Statistics; OSD (2018).

Based on World Input-Output Database (WIOD) we estimated that the TC sector produces 64.8 billion Turkish Lira (TL) worth of gross value added (GVA) in 2013constituting 4.8 percent of total GDP. With indirect (25.5 billion TL) and induced (27.6 billion TL) effects, total GVA produced by the TC sector amounted to 8.9 percent of WIOD based GDP (PGlobal, 2014).

While the TC sector relies on modern equipment and newer technologies, bulk of its products remained to be traditional ones with relatively low value-added per unit. Apparently, Turkish clothing sector has been slow in shifting from contract manufacturing to global brands, to creating its own globally recognized brands.

Also the Turkish textile sector has been slow in transforming its production composition to constitute more of technical textiles. Despite the progress in technical textile production during the past years the share of technical textiles in total textile production is not yet at adequate levels. Specifically, while the total fibre consumption for technical textiles was 101 thousand tonnes in 2000, it elevated to 188 thousand tonnes in 2010 (or, 13 percent of total fibre consumption) (CIRFS, 2011). Technical textiles export has also been following an upward trend. While the total value of technical textile export was USD 425 million in 2000, it reached USD 1.22 billion in 2010 and to 1.60 billion USD to 2014. With this amount Turkey constituted 1.6 percent of world total technical textile exports and ranked the $18^{\text {th }}$ largest exporter (ITKIB, 2012 and ITKIB, 2015).

Thus, compared to its relatively superior role in the overall TC industry, Turkey lags behind in technical textiles. Nevertheless, the country's infrastructure in textiles and its expanding production and product diversification in technical textiles may lead to further expansion in technical textiles in the years ahead. Hence, Turkey is in a divergence point on the TC cycle. In order to stand against competition from low cost textile and clothing manufacturers such as, China, India and Bangladesh, the future of Turkish TC industry depends on transforming itself to high value added TC production either through branding and/or technical textiles.

\subsection{Bangladesh}

Bangladesh is an emerging major player and one of the largest TC exporters in the world. The TC industry is a major source of employment in the country and its growth rates are still high. The 
growth of TC exports has been a result of the country's emergence as a part of the international supply chains and the benefits from exporting to larger markets. The country is slowly climbing on the value chain by moving up to Free-on-Board (FOB) production arrangements from CutMake-Trim (CMT). ${ }^{14}$ As such the country can be identified to be in the early to middle to Stage II of the TC cycle. Further, in Bangladesh, TC can be considered the single most important industrial sector which may trigger the development of other industrial sectors on an internationally competitive basis.

Bangladesh has a long experience in TC production for the domestic market. However, the export-oriented clothing industry in Bangladesh commenced in 1977 (Staritz, 2010, p. 134). In 1979, a Korean and Bangladeshi joint venture commenced operation in Chittagong (Quddus and Rashid, 2000). Following that, many foreign investors from Korea, Taiwan, and many other East Asian countries relocated their operations to Bangladesh in order to utilize the unused quota under the Multi-Fibre Arrangement (MFA) and abundant cheap labor.

The Bangladeshi government facilitated domestic firms by introducing "back to back letters of credit" policies in 1980 and provided special privileges for local firms (e.g. bank loan with low interest, tariff exemptions for inputs and equipment, and free warehouse facilities) (Ahmed, 2009). In addition, the government introduced an industrial policy that limited FDI to the Export Processing Zones until 2006 (Dunn, 2008, p. 4). As a result, domestically owned clothing firms have expanded and dominated the industry. Number of TC factories and employment increased rapidly after 1980s.

The clothing industry is the largest manufacturing industry in Bangladesh, accounting for 81.1 percent of the total exports of the country in 2013 (BGMEA, Trade Information, 2015). Indeed, Bangladesh has emerged as the 2nd largest clothing exporting country in the world since 2011 considering EU 28 as one country. ${ }^{15}$ With regard to the volume of exports, the industry exported USD 31.6 million in 1983, USD 4,349.4 million in 1999, and USD 24,491.8 million in 2013. In terms of export destinations, the EU is the largest market, accounting for 60.2 percent, followed by the US (21 percent) in 2013.

14 CMT is the lowest value-added activity, in which global buyers supply all necessary intermediate materials to local producers, the latter of which engage themselves in the labor-intensive processes of cutting, sewing and trimming. On the other hand, FOB arrangement includes greater value added activities. FOB-1 consists of local producers taking the responsibility of sourcing intermediate materials and production, whereas in FOB-2, local producers conduct sourcing of intermediate materials, all levels of production, and design. In this context, CMT, FOB-1, and FOB-2 are equivalent to OEA (original equipment assembly), OEM (original equipment manufacturer) and ODM (original design manufacturer), respectively in the electronics industry (see Alam and Natsuda, 2013).

15 For instance, except for EU 28, the largest exporting country was China (accounting for USD 154 billion and 37.3 percent), followed by Bangladesh (USD 20 billion and 4.8 percent), India and Turkey (USD 14 billion and 3.5 percent) in 2011 (WTO, 2012, p. 132). 


\subsection{Characteristics of the Bangladeshi TC Industry}

There are two key characteristics in the TC industry in Bangladesh. Firstly, in relation to the textile industry, although Bangladesh exported USD1.89 billion of textile products in 2013, Bangladesh is also a net importer of textiles with USD 6.22 billion of imports (WTO 2014, p.1078). The availability of intermediate materials such as yarn and fabric in Bangladesh is still limited. The domestic production (supply) capacity of yarn and fabric in Bangladesh cannot meet the local demand, accounting for 65.4 percent and 61.4 percent of local consumption, ${ }^{16}$ respectively in FY 2011 (USDA, 2013, p. 8).

Secondly, the Bangladeshi clothing industry seems to have been successfully upgrading in global production arrangements in the recent years. The lowest value-added activity, CMT arrangement dominated the TC industry until the mid-2000. According to World Bank (2005), 75 percent (over 2,000 firms) were engaged in CMT arrangements, while 25 percent were engaged in the FOB arrangement. More recently, according to the survey of 69 Bangladeshi clothing firms conducted in 2012, 85 percent (56 firms) and 6 percent ( 4 firms) were engaged in FOB-1 and FOB-2, respectively in comparison with only 9 percent (or 6 firms) of the CMT arrangement (Alam and Natsuda, 2013). In this context, Bangladeshi clothing firms have conducted industrial upgrading effectively, successfully shifting from the lowest to higher value production arrangements.

\subsection{Cambodia}

Another emerging country in TC industry, Cambodia has, in the last two decades, recorded very high growth rates and employment that is almost entirely directed to exports. Best identified at the beginning of the Stage II in the TC cycle, Cambodian experience with TC suggests interesting peculiarities as well as "standard" behavior. Firstly, the country has developed a clothing industry without a textile industry; the rapid growth has come almost entirely from clothing production. The country still struggles with establishing a textile industry. Secondly, from almost zero in 1993, TC now employs a significant part of Cambodia's workforce. Thirdly, as in Bangladesh, the growth of clothing exports has been a result of the country's becoming part of the international supply chains and the country benefits from exporting to larger markets. Fourthly, the current status of the Cambodian clothing industry is one where intermediate goods (textile) are imported and converted into finished products through low-cost labor based simple CMT. Lastly, as in Bangladesh (but less pronounced) TC can be considered the single most important industrial sector with a significant employment which is slowly triggering the development of other industrial sectors on an internationally competitive basis.

The origin of the Cambodian TC industry can be traced back to the French colonial era (18631953) with a small scale production based on locally produced silk and cotton. Industrial production of textiles commenced after the independence in 1954 with the establishment of

16 Local production of Yarn and Fabrics accounted for 0.615 and 3.8 million tons in comparison with 0.94 and 6.18 million tons, respectively in FY 2011 (USDA, 2013, p. 8). 
state-owned textile company, SONATEX, which expanded textile and clothing factories since the late 1950s (Sok et al., 2001). However, the industry could not stay due to political and social upheaval for nearly 3 decades.

The current export-oriented clothing industry in Cambodia was founded after the Paris Peace Agreement in 1991 and followed by the first national election in 1993 with foreign investments from Hong Kong, Taiwan, Malaysia and Singapore (Bargawi, 2005). At the outset of this reemergence phase, the industry accounted for 20 factories and employed 18,700 workers in 1995. Since then, during the last 2 decades, the Cambodian clothing industry has grown rapidly. Although the number of factories and employment in the industry has declined after Lehman shock to 243 factories and 278,400 workers in 2009, the clothing industry in Cambodia recovered, accounting for 375 factories and 373,000 workers in 2012 which constitute 21 percent of the industrial and 5.2 percent of the total employment.

There are several characters of the development of the Cambodian clothing industry. Firstly, the industry has been successful in accessing major markets under favorable market access policy. In 1996, Cambodia was granted the status of MFN (Most Favored Nation) by the United States and the EU, which accelerated foreign direct investments into the Cambodian clothing sector, for the purpose of utilizing the low tariff export rate in those markets (Natsuda et al. 2010). In the US market, the US government, ILO (International Labor Organization) and the Cambodian government jointly introduced "Better Factories Cambodia" scheme by linking export quotas with labor standards and concluded a bilateral 3 year-trade agreement on textile and apparel (TATA) in 1999. It was later extended to December 2004, which was the end of MFA (Multi Fibre Agreement) (Chiu, 2007). In the EU market, 3.5 year textile agreement was formed in 1999, which allowed Cambodia to enjoy duty and quota free access to the EU market and later "Everything but Arms (EBA)" scheme, which provides duty and quota free access to all Cambodian exports to the EU market since 2001.

The Cambodian clothing exports expanded by approximately 4.3 times from 1997 to 2000 and a further 5.2 times from 2000 to 2013 to USD 4,967 million. Although the US market has remained the largest export destination since 1990s, more recently, the EU market has expanded from USD 693 million in 2010 to USD 1,757 million in 2013.

Secondly, the process of industrialization and the ownership of the industry can be addressed. Unlike neighboring countries of Vietnam or Bangladesh, Cambodia did not experience importsubstitution industrialization. Rather, the government has shifted directly from a centrally planned market system to a free market economy since the mid-1990s. Consequently, the clothing industry in Cambodia came to rely on the free market system and developed in accordance with foreign investments. The ownership of local capital is extremely limited in Cambodia, accounting for only 7 percent in comparison with 93 percent of foreign capitals (Taiwan 25 percent, Hong Kong 19 percent, China 18 percent, and Korea 10 percent) in 2008 (Natsuda et al., 2010, p.7). 
Thirdly, low level of production orientation in global value chain and lack of supporting industry can be major issues in the Cambodian clothing industry. The industry highly depends on the CMT arrangement, which is based on a competitive advantage of merely cheap labor. The production arrangements in Cambodia were estimated that CMT and FOB accounted for 60 percent and 25 percent of the clothing factories and the other 15 percent of factories were subcontractors of CMT or FOB activities in 2008 (Natsuda et al., 2010, p. 12). Furthermore, the Cambodian clothing industry heavily depends on almost entirely on imported yarn, fabrics, and accessories. Indeed, over 90 percent of input are imported (Staritz, 2010). For instance, Cambodia imported USD 3,080 million of textile products, which accounts for 23.7 percent of the total merchandise import of the country in 2013 (WTO, 2014, p.108). It seems to be a big challenge for Cambodia to diversify the clothing industry and develop the domestic textile industry, due to the following five reasons: 1) lack of local fibre production in cotton and men made fibres; 2) more capitalintensive investment required in the textile industry; 3) lack of infrastructure, particularly water and electricity supply; 4) more knowledge and skill-intensive human resource required in the industry; and 5) competition with China (in terms of price quality, lead times) (Staritz, 2010, p. 120-121).

In a nutshell, the Cambodian clothing industry imports intermediate goods (textile) and conduct a simple CMT operation by utilizing cheap labor. In this context, the Cambodian clothing industry is still located in the lowest value chain in the world, and still faces a difficulty in diversifying the industry.

\section{Conclusion}

Clothing and textile industries have played a pioneering role in the overall industrialization of the UK during the industrial revolution and since then the sector has played a similar role in the industrialization of a number of other countries. Nevertheless, many early developers, like Japan, have subsequently abandoned CT manufacturing and lost their CT industries mostly due to cost differentials with newly developing countries. Industrial countries that could maintain their CT sectors, such as the USA, managed to do so by successfully transforming their CT industries into high value added manufacturing through branding (fashion industry) or developing technical textiles products. We further exhibited that, industrialization process with CT sector recurs even today in countries such as Bangladesh and Cambodia.

Hence, based on the historical experiences in several countries, we suggest that between the birth of the industrial CT sector and its demise or transformation, the industry goes through four distinct phases. In the first phase of the cycle, CT production at the industrial level emerges and grows slowly. As such, the TC sector provides a critical entry point for the unskilled workforce into the labor market and it converts low-skilled labors into industrial workers. In the second stage, growth accelerates when CT starts to become a large industrial sector in terms of employment, gross value added and exports. Accordingly, the TC sector facilitates capital accumulation and 
initiates overall industrialization of the country by means of investments in other industries. In the subsequent phase, the CT sector "matures" displaying low or zero growth rates, and falling shares in total value added or exports of the country. In the last phase, CT production either by and large disappears or gets transformed into a high value added product and remains at a lower intensity compared to before.

These regularities, comprises useful recommendations for industrialization of countries that are at their earlier stages of CT cycle as well as for countries that have already reached a mature level in the cycle but facing challenges in maintaining CT production. The stylized regularities also provide a useful guideline for countries that are yet to start their industrialization processes, such as some sub-Saharan African countries.

Future research can enrich the literature by looking at various related questions. Firstly, similar cycles in other industries can be verified. Secondly, the CT cycle, or possible similar cycles in other industries, can be refined by different country cases in terms of employment, exports or gross value added. Thirdly, positive spillovers from CT to other industrial sectors can be examined in different countries and plausible paths of overall industrialization can be identified for policy purposes.

\section{References}

AHMED, N. (2009). Sustaining Ready-made Garment Exports from Bangladesh. Journal of Contemporary Asia, 39(4): 597-618.

ALAM, S., NATSUDA, K. (2013). The Competitive Factors of the Bangladeshi Garment Industry in the Post-MFA Era. Ritsumeikan Asia Pacific University WP, RWP-13003.

BARGAWI, O. (2005). Cambodia's Garment Industry - Origins and Future Prospect. ESAU (Economic and Statistics Analysis Unit) Working Paper, No 13.

BARROW, C. (2000). Economic Impacts of the Textiles and Apparel Industries in Massachusetts. Report for the Donahue Institute of Governmental Affairs.

BGMEA (Bangladesh Garment Manufacturers and Exporters Association) Trade Information http://www. bgmea.com.bd/home/pages/TradeInformation\#.VSxrH_msWCp (Accessed On: 13.04.2015)

BRITISH FASHION COUNCIL (2010). The Value of the UK Fashion Industry. London.

BRITISH FASHION COUNCIL (2015). The Economic Value of the UK's Fashion Industry in 2015. London.

CAMERON, R. AND NEAL, L. (2003). A Concise Economic History of the World: From Paleolithic Times to the Present. $4^{\text {th }}$ Edition. New York: Oxford University Press.

CIRFS (European Man Made Fibres Association) (2011). World Market for Technical Textiles to 2017. International Newsletters Ltd.

CHAUDHURI, K.N. (1974). The Structure of Indian Textile Industry in the Seventeenth and Eighteenth Centuries. Indian Economic and Social History Review, 11 (2-3): 127-82.

CHI, T. (2010). An Empirical Study of Trade Competitiveness in the U.S. Technical Textile Industry. Journal of Textile and Apparel, Technology and Management, 6(4): 1-19.

CHIU, C.C.H. (2007). Workplace Practices in Hong Kong-Invested Garment Factories in Cambodia. Journal of Contemporary Asia, 37(4): 431-448. 
CLIFFORD, S. (2013). U.S. Textile Plants Return, with Floors Largely Empty of People. New York Times, 19 September 2013. http://www.nytimes.com/2013/09/20/business/us-textile-factories-return. html?pagewanted=all\&_r=0 (Accessed On: 15.05.2015)

CONRAD, J.L. (1995). Drive that Branch: Samuel Slater, the Power Loom, and the Writing of America's Textile History. Technology and Culture, 36(1): 1-28.

DANGERFIELD, G. (1965). The Awakening of American Nationalism: 1815-1828. New York: Harper \& Row.

DATTEL, G. (2009). Cotton and Race in the Making of America: the Human Costs of Economic Power. Plymouth, UK: Ivan R. Dee.

DUNN, J. (2008). The Ready-made Garment Industry in Bangladesh: an Update. Washington, DC: International Monetary Fund.

FARRELL, R. (2008). Japanese Investment in the World Economy: a Study of Strategic Themes in the Intrenationalisation of Japanese Industry. Cheltenham, UK: Edward Elgar Publishing.

FRANCKS, P. (2011). Kimono Fashion: the Consumer and the Growth of the Textile Industry in Pre-war Japan. In: Francks P., Hunter J., Editors. The Historical Consumer: Consumption and Everyday Life in Japan, 1850-2000. New York: Palgrave Macmillan.

GARRATY, J.A. (1997). The American Nation: a History of the United States. $9^{\text {th }}$ Edition. Boston: Addison Wesley.

GEREFFI, G. (2000). The Transformation of the North American Apparel Industry: is NAFTA a Curse or Blessing? Integration and Trade, 4(11): 47-95.

HARLEY, C.K. (1998). Cotton Textile Prices and the Industrial Revolution. Economic History Review, 51(1): 49-83.

HAWKE, D. F. (1998). Nuts and Bolts of the Past: a History of American Technology, 1776-1860. New York: Harper \& Row.

ITKIB (2012). Türkiye’nin Teknik Tekstil Ticareti Üzerine Güncel Bilgiler. Istanbul: ITKIB Genel Sekreterliği, AR \& GE ve Mevzuat Şubesi.

ITKIB (2015). Teknik Tekstil Sektörüne İlişkin Güncel Bilgiler. Istanbul: ITKIB Tekstil, Deri ve Halı Şubesi.

KALDOR, N. (1961). Capital Accumulation and Economic Growth. In: Lutz F.A., Hague D, Editors. The Theory of Capital. London: McMillan.

KALDOR, N. (1966). Causes of Slow Rate of Economic Growth of the United Kingdom. Cambridge, UK: Cambridge University Press.

KALDOR, N. (1967). Strategic Factors in Economic Development. Ithaca: New York State School of Industrial and Labour Relations, Cornell University.

McNAMARA, D.L. (1995). Textiles and Industrial Transition in Japan. Ithaca, New York: Cornell University Press.

MESSE FRANKFURT (2011). Technical textiles - a Market with Enormous Potential. http://www. fibre2fashion.com/news/company-news/messe-frankfurt/newsdetails.aspx?news_id=94612 (Accessed On: 17.05.2015)

MEYER, D. (2003). The Roots of American Industrialization. Balltimore: The Johns Hopkins University Press.

MITTELHAUSER, M. (1997). Employment Trends in Textiles and Apparel, 1973-2005. Monthly Labor Review, August 1997: 24-35.

MUKUND, K. (1992). Indian Textile Industry in 17th and 18th Centuries: Structure, Organisation and Responses. Economic and Political Weekly, 27(38): 2057-65. 
MURRAY, L. (1995). Unraveling Employment Trends in Textiles and Apparel. Monthly Labor Review, August 1995: 62-71.

NATSUDA, K., GOTO, K., THOBURN, J. (2010). Challenges to the Cambodian Garment Industry in the Global Garment Value Chain. European Journal of Development Research, 22(4): 469-93.

NORTH JERSEYS INTERNET MAGAZINE. Silk City - Paterson, New Jersey. Industrial Revolution in North Jersey. http://www.rt23.com/history/Paterson_NJ-silk_city.shtml (Accessed On: 21.03.2015)

OHKAWA, K. (1979). Production Structure. In: Ohkawa K., Shinohara M. Editors. Patterns of Japanese Economic Development: a Quantitative Appraisal. New Haven and London: Yale University Press.

OSD (Otomobil Sanayicileri Derneği) (2018). Otomotiv Sanayi Dış Ticaret Raporu. 1. Çeyrek 2018

PGLOBAL (2014). Tekstil ve Hazır Giyim Sektörü ve Türk Ekonomisindeki Yeri. Istanbul: Turkish Textile Employers' Association.

PREYER, N.W. (1959). Southern Support of the Tariff of 1816 - a Reappraisal. The Journal of Southern History, 25(3): 306-22.

QUDDUS, M., RASHID S. (2000). Entrepreneurs and Economic Development: the Remarkable Story of Garment Exports from Bangladesh. Dhaka: The University Press Limited.

ROSE, M. (1991). International Competition and Strategic Response in the Textile Industries since 1870, Business History, 32(4): 1-8.

SAXONHOUSE, G. (1974). A Tale of Japanese Technological Diffusion in the Meiji period. The Journal of Economic History, 34(1): 149-165.

SMITH, T.C. AND VUCINICH W.S. (1955). Political Change and Industrial Development in Japan: Government Enterprise 1868-1880. Stanford: Stanford University Press.

SOK, H., CHEA H., SIK B. (2001). Cambodia’s Annual Economic Review - 2001. Phnom Penh: Cambodia Development Resource Institute.

STARITZ, C. (2010). Making the Cut? Low-Income Countries and the Global Clothing Value Chain in a Post-Quota and Post-Crisis. Washington DC: World Bank.

SUH, H.O.M.W. (2003). What is Happening to the US Textile Industry? Reflections on NAFTA and US Corporate Strategies. Journal of Fashion Marketing and Management: An International Journal, 7(2), 119-37.

TANIGUCHI, F. (1991). The Economic Outlook for Textiles and Clothing in the 1990s: Developments in the Textile and Clothing Industry in Japan. Journal of the Textile Institute, 82(2), 195-202.

TUIK (Turkish Statistical Institute) Foreign Trade Statistics. http://biruni.tuik.gov.tr/disticaretapp/menu.zul (Accessed On: 09.03.2019)

USDA (2013). Bangladesh Cotton and Products Annual. United States Department of Agriculture: Washington DC.

WB (World Bank) (2005). End of MFA Quotas: Key Issues and Strategic Option for Bangladesh Garment Industry. World Bank: Washington, DC.

WB (2019). World Development Indicators. http://data.worldbank.org/data-catalog/world-developmentindicators (Accessed On: 01.04.2019)

WTO (World Trade Organization) $(2012,2014,2018)$. International Trade Statistics. Geneva. 